•编者按・

\title{
了解生态网络需要监测植物与传粉者的相互作用
}

\author{
黄双全 ${ }^{*}$ \\ (华中师范大学生命科学学院进化与生态学研究所, 武汉 430079)
}

\section{A better understanding of ecological networks needs studying plant- pollinator interactions}

\author{
Shuangquan Huang* \\ Institute of Evolution and Ecology, School of Life Sciences, Central China Normal University, Wuhan 430079
}

植物与传粉者相互作用是我们绿色星球最重 要的生态过程之一, 因为绝大多数被子植物依赖动 物帮助传递花粉, 而后受精结实; 同时, 植物产生的 花蜜花粉等营养物质作为传粉者的报偿。据Ollerton (2017)估计，全球传粉动物约有35万种，种类最多 的是昆虫, 还包含鸟类一千余种、蝙蝠二百余种和 不能飞行的哺乳动物百余种。其中, 鳞翅目 (蝶和蛾) 昆虫占所有传粉者种类的 $40 \%$, 有 14 万余种; 其次 是鞘翅目 (甲虫类), 占 $22 \%$, 约有 7.7 万种; 膜翅目 (蜂类等)占 $20 \%$, 约有7万种。在一些低温的生境中, 雀形目鸟类的传粉作用逐渐被人们所认识; 在一些 岛屿上, 爬行动物蚚蜴是一类重要的传粉者。传粉 者为野生植物和农作物提供的传粉服务有巨大的 生态价值, 仅在作物生态系统中每年就超过 2 千亿 美元(IPBES, 2016)。2016年3月生物多样性和生态系 统服务政府间科学-政策平台 (Intergovernmental Science-Policy Platform on Biodiversity and Ecosystem Services, IPBES)提出了首个专题评估报告《传 粉者、传粉与粮食生产》(田瑜等, 2016), 指出了传 粉和传粉者在生态系统中的重要价值, 强调全球传 粉者面临的危机, 体现在一些重要传粉者种类的多 样性和种群呈下降趋势。

2017年1月Functional Ecology出版了 “植物与传 粉者互作及传粉危机: 从花到景观层次的透视” 专 辑(Nicolson \& Wright, 2017); 专辑的8篇文章从不 同方面阐述了影响植物与传粉者相互作用构成的 传粉系统(pollination system)的健康, 主要危害包括 生境破坏、化学污染、气候变化和人为干扰等。加 拿大农业相关部门建立了一个有关蜜蜂的交流平 台(http://www.beesmatter.ca/), 提出影响蜂群健康的 一个关键因素是能否获取充足的营养。为缓解传粉 者受食植物资源的短缺, 提倡人们在自家庭院里种 植蜜粉源植物, 建设传粉者友好的花园 (pollinator friendly garden), 以保护蜜蜂等传粉者。2015年5月, 美国白宫颁布了由美国环境保护局和美国农业部 联合起草的《关于保护蜜蜂及其他传粉者的国家战 略发展规划》白皮书, 试图通过跨学科的科学合作 研究、提高公众对传粉者的认知程度、加强政府与 各种组织的合作关系和保护传粉者栖息地等 4 个方 面加强传粉者的保护和恢复(贾翔宇等, 2018)。

在农业生态系统中, 欧美一些国家在 20 世纪 40 年代已开始监测家养蜜蜂的种群动态及其传粉作 用(谢正华等, 2011)。我国目前已在不同的陆地生态 系统中建立多个台站监测生态环境和动植物群落 构成的变化, 但相对于大型动物的监测而言还极少 监测植物与传粉者互作网络。如果能借助中国生态 系统研究网络等平台开展传粉系统的监测, 不仅可 以建立传粉系统的监测体系、深入调查植物与传粉 者互作动态, 而且可以探究影响生态网络的结构及 其稳定性的因素, 为了解生态网络的维持机制提供 新信息。

我国已制定了多项保护濒危动植物的措施，大 
大促进了生物多样性的保护。不少学者也意识到传 粉者的重要性, 例如, 徐环李等(2009)曾撰文呼吁 保护我国野生的传粉蜂。在生态保护的实践中, 人 们认识到维持生物间关系的生态过程十分关键。例 如兰科植物往往需要特殊的传粉者才能结实(如果 迁地保护就可能导致相应传粉者的缺失)、一些作物 不能利用家养蜜蜂授粉等。又如, 20世纪50年代, 养 蜂人就注意到中华蜜蜂 (Apis cerana) 采食油茶 (Camellia oleifera)花粉后, 幼虫中毒死亡(朱永谦, 1957)。可见，维持植物与传粉者的互作关系需要了 解传粉系统的属性是特化的还是泛化的。而通过监 测植物与传粉者的互作网络获得的知识, 又可为自 然保护区的建立和生物多样性的就地保护提供科 学依据, 为农林业生态系统的健康发展提供科学的 管理策略。近年来, 新技术(如红外相机技术)与新方 法(如社交网络分析方法的发展)被运用到生态网络 的研究中, 极大地拓展了物种种间关系、群落生态 学研究的内容(Fang \& Huang, 2016)。

为推动我国开展植物与传粉者互作网络的监 测, 我们向《生物多样性》期刊建议组织本期“传粉 网络的监测”专辑, 在酝酿和组稿过程中, 得到本 刊主编、多位不同领域的学者和编辑部的大力支 持。本专辑收录了10篇论文, 其中关于方法学的论 述2篇, 传粉系统与蜂类传粉者的相关综述 4 篇, 研 究报告3篇, 有关IPBES评估报告1篇。

由于访花的动物并不一定都传粉, 因此判定是 否为传粉者是传粉网络研究的基础; 特别是一些蜂 类昆虫实际上是采粉者或称为盗粉者(pollen thief或 robber), 它们将植物产生的花粉(包含精子)大量采 集运回巢穴，而不是传送到植物的柱头上。家养蜜 蜂就是高效的花粉收集者, 它们有特化的花粉刷将 花粉转移到后足花粉筐中, 极大减少了花粉落置到 柱头上的机会，造成花粉的巨大损失。花粉传递效 率的检验表明这类高效的花粉收集者实际上是低 效的传粉者，曾被称为 ugly pollinator (Wilson \& Thomson, 1991)。例如, 荷花(Nelumbo nucifera)上常 见蜜蜂采集花粉, 其有效的传粉者却是甲虫( Li \& Huang, 2009); 冬季开花的金花茶(Camellia petelotii) 虽然也有家养蜜蜂访花, 但有效的传粉者是太阳鸟 (Sun et al, 2017)。蜜蜂虽然在这些物种的花上频繁 访问, 但很少接触柱头, 传粉作用甚微。童泽宇等 (2018)探讨了监测不同传粉者类群的方法, 强调了
区分访花者和传粉者的重要性。针对一些肉眼难以 直接观察的传粉动物，介绍了前人所采取的间接、 有效的区分方法，为未来传粉网络的监测提供了借 鉴。郎丹丹等(2018)讨论了DNA条形码和高通量测 序技术在传粉网络研究中的应用前景，提出利用高 通量测序技术结合无PCR扩增的“超级条形码”技术， 有望实现对混合花粉样品进行定性及相对定量的 监测。作者意识到传粉昆虫虫体携带花粉的DNA总 量达不到“宏基因组”技术所要求的量，提出将样品 混合。然而, 样品混合之后如何分析个体之间的差 异呢? 这种方法能否反映真实的传粉网络值得考 虑。另外要注意的是，虫体上不同部位携带的花粉 量与起传粉作用的花粉量不是对应关系(Tong \& Huang, 2018), 例如盗粉者所采集的花粉。新技术往 往会给某个领域带来学科生长点, 我们期待此类技 术在传粉生态学中的应用。

植物拥有多样的性系统与繁殖策略，这些特性 会影响其与传粉者之间的相互作用。克隆植物如果 有多个分株同时开花，且传粉者就近访问同一个个 体的花，同株异花传粉的可能性就会增加，这种传 粉者促进的自交对有性生殖不利。田吴和廖万金 (2018)综述了近年来克隆生长对传粉成功的影响研 究，包括模拟与野外实验，结果表明传粉者在同一 克隆内的访花数量并不会随克隆增大而持续增大， 同株异花传粉主要发生在分株内, 为人们理解克隆 植物或多花序植物的传粉机制提供了可能的解释。 王娟等(2018)调查了新疆郁金香(Tulipa sinkiangensis)一个野生居群个体性别7年间的动态变化。她们 发现郁金香属虽为两性花植物，但新疆郁金香个体 的性别并不是一成不变的, 有些个体会产生雄花。 虽然该居群雄花的比例一直呈下降趋势的原因仍 不清楚, 但该研究多年的跟踪记录提示我们监测传 粉网络不仅要监测传粉者的动态，而且要监测植物 居群的开花动态及个体性别。特别是对雌雄异株植 物, 如果动物只在雄株上访花, 很可能是盗粉者而 不起传粉作用。当扩散到新的生境后，依赖特化传 粉者的植物很可能因传粉者缺失而无法拓殖, 而那 些由泛化传粉者传粉的植物则很可能成为入侵种。

Baker (1955)曾预测雌雄异株或自交不亲和的植物 因为缺乏交配对象而难以长距离扩散。相反, 克隆 植物或自交亲和的植物就容易开拓新的生境。孙士 国等(2018)综述了近年来入侵植物的繁殖策略及其 
对本土植物繁殖影响的研究。入侵植物在入侵地是 否发生了繁殖策略的转变? 不论是对某一个区域 还是综合案例的分析, 总体来看入侵植物的繁殖策 略均符合Baker法则。入侵植物可能会与本土植物竞 争传粉者, 促进本土植物繁殖性状的分化。那么比 较有入侵种的种群和无入侵种的本土留存物种的 种群, 将为探讨性状演化和特征替代提供了机会。

即使在恶劣的环境中, 开花植物也有促进异花 传粉的策略。吉乃提汗.马木提等(2018)研究了新疆 北部荒漠春季开花的一年生短命植物异喙菊 (Heteracia szovitsii)的繁殖策略。该种头状花序黄 色、单花期约 $3 \mathrm{~h}$, 虽然大风和低温常常限制昆虫活 动, 但在晴天也吸引了隧蜂、食蚜蝇类昆虫访花。 他们注意到隧蜂虫体上携带有大量异嗄菊的花粉。 单花开放时间(花寿命)受传粉环境的影响, 王玉贤 等(2018)对青藏高原高寒草甸不同海拔的11种开花 植物进行了套袋、补充授粉处理并与自然传粉的花 寿命作了比较, 实验结果与预期相符: 授粉显著缩 短了花寿命，不授粉延长了花寿命。他们还发现高 海拔植物的花寿命对补充授粉处理更敏感, 可塑性 比低海拔的更强, 这一结果为高海拔(传粉者稀少 的高寒环境)植物的趋同适应提供了新证据。这些研 究案例提示我们在监测植物与传粉者互作网络时 需要了解植物的开花习性和传粉者的活动规律。

熊蜂是一类体型大、耐低温的蜜蜂科昆虫, 是 一些农作物不可替代的传粉者，也是温带特别是高 海拔地区的一类重要传粉动物(Goulson, 2010)。我 国西南山地是全球熊蜂多样性中心, 黄家兴和安建 东(2018)论述了中国熊蜂资源挖掘以及人工利用与 保护策略。他们厘清了中国境内有熊蜂125种, 近 10 年来有 6 种本土熊蜂驯养成功, 改善了我国依赖进 口熊蜂为特殊农作物(如茄科植物)提供传粉服务的 局面。大蜜蜂(Apis dorsata)为亚洲热带地区特有的 一种野生蜜蜂, 杨培等(2018)论述了大蜜蜂的生物 学特性、面临的威胁及保护策略, 并针对栖息地破 坏、全球气候变化、农药杀虫剂等的滥用、病虫害 感染等受威胁因素提出了相应的应对措施。

人类生存与发展依赖自然生态系统的健康。虽 然主要粮食作物(禾本科植物)是风媒传粉, 但蔬菜、 瓜果类基本依赖动物传粉, 而人类不断增长的物质 需求(如蔬菜水果在食物中的比重增加), 更加依赖 动物传粉的作物。认识到传粉者衰减的危机, 2002
年《生物多样性公约》第6次缔约方会议建立了国 际传粉者行动(International Pollinator Initiative)计 划。联合国粮农组织(Food and Agriculture Organization (FAO) of the United Nations) 开设了专题网站 强调传粉在可持续农业中的重要性(http://www. fao.org/pollination), 并提供传粉者群落监测和管理 的手册供下载。通过监测植物与传粉者的互作网络 可以构建传粉者的食物网, 有助于人们了解传粉者 在不同开花植物上的受食行为及其对传粉的影响; 特别是传递异种的花粉，引起同期开花植物之间的 生殖干扰，导致种间的传粉竞争(Fang \& Huang, 2016)。深入开展传粉网络的监测与研究, 将为认识 群落构建、物种共存的机制提供新的视角。

\section{参考文献}

Baker HG (1955) Self-compatibility and establishment after "long distance" dispersal. Evolution, 9, 347-349.

Fang Q, Huang SQ (2016) A paradoxical mismatch between interspecific pollinator moves and heterospecific pollen receipt in a natural community. Ecology, 97, 1970-1978.

Goulson D (2010) Bumblebees: Behaviour, Ecology and Conservation. Oxford University Press, Oxford.

Huang JX, An JD (2018) Species diversity, pollination application and strategy for conservation of the bumblebees of China. Biodiversity Science, 26, 486-497. (in Chinese with English abstract) [黄家兴, 安建东 (2018) 中国熊蜂多样 性、人工利用与保护策略. 生物多样性, 26, 486-497.]

IPBES (2016) Summary for policymakers of the assessment report of the Intergovernmental Science-Policy Platform on Biodiversity and Ecosystem Services on pollinators, pollination and food production. In: Intergovernmental SciencePolicy Platform on Biodiversity and Ecosystem Services Deliverables of the 2014-2018 Work Programme (eds Potts SG, Imperatriz-Fonseca VL, Ngo HT, Biesmeijer JC, Breeze TD, Dicks LV, Garibaldi LA, Hill R, Settele J, Vanbergen AJ, Aizen MA, Cunningham SA, Eardley C, Freitas BM, Gallai N, Kevan PG, Kovács-Hostyánszk A, Kwapong PK, Li J, Li X, Martins DJ, Nates-Parra G, Pettis JS, Rader R, Viana BF), pp. 1-28. IPBES, Bonn, Germany.

Jia XY, Bai B, Zhang JQ, Huang Y (2018) The effects of IPBES deliverables on global biodiversity conservation strategy - an analysis based on the U. S. pollinator protection policy. Biodiversity Science, 26, 527-534. (in Chinese with English abstract) [贾翔宇, 白涁, 张洁清, 黄艺 (2018) IPBES评估报告对全球生物多样性保护的影响一以美 国传粉者保护政策为例. 生物多样性, 26, 527-534.]

Lang DD, Tang M, Zhou X (2018) Qualitative and quantitative molecular construction of plant-pollinator network: Application and prospective. Biodiversity Science, 26, 445-456. (in 
Chinese with English abstract) [郎丹丹, 唐敏, 周欣 (2018) 传粉网络构建的定性定量分子研究: 应用与展望. 生物多样性, 26, 445-456.]

Li JK, Huang SQ (2009) Effective pollinators of Asian sacred lotus (Nelumbo nucifera): Contemporary pollinators may not reflect the historical pollination syndrome. Annals of Botany, 104, 845-851.

Mamut J, Cheng CJ, Tan DY (2018) Heteromorphism of florets and reproductive characteristics in Heteracia szovitsii (Asteraceae), a desert ephemeral annual herb. Biodiversity Science, 26, 498-509. (in Chinese with English abstract) [吉乃 提汗. 马木提, 成小军, 谭敦炎 (2018) 荒漠短命植物异喙 菊的小花异形性及繁殖特性. 生物多样性, 26, 498-509.]

Nicolson SW, Wright GA (2017) Plant-pollinator interactions and threats to pollination: perspectives from the flower to the landscape. Functional Ecology, 31, 22-25.

Ollerton J (2017) Pollinator diversity: Distribution, ecological function, and conservation. Annual Review of Ecology, Evolution, and Systematics, 48, 353-376.

Sun SG, Huang ZH, Chen ZB, Huang SQ (2017) Nectar properties and the role of sunbirds as pollinators of the golden-flowered tea (Camellia petelotii). American Journal of Botany, 104, 468-476.

Sun SG, Lu B, Lu XM, Huang SQ (2018) On reproductive strategies of invasive plants and their impacts on native plants. Biodiversity Science, 26, 457-467. (in Chinese with English abstract) [孙士国, 卢斌, 卢新民, 黄双全 (2018) 入侵植物的繁殖策略以及对本土植物繁殖的影响. 生物 多样性, 26, 457-467.]

Tian H, Liao WJ (2018) Consequences of clonal growth on pollinator visitation in flowering plants. 26, 468-475. (in Chinese with English abstract) [田昊, 廖万金 (2018) 克隆 生长对被子植物传粉过程的影响. 26, 468-475.]

Tian Y, Lan CZ, Xu J, Li XS, Li JS (2016) Assessment of pollination and China's implementation strategies within the IPBES framework. Biodiversity Science, 24, 1084-1090. (in Chinese with English abstract) [田瑜, 兰存子, 徐靖, 李秀 山, 李俊生 (2016) IPBES框架下的全球传粉评估及我国 对策. 生物多样性, 24, 1084-1090.]

Tong ZY, Huang SQ (2018) Safe sites of pollen placement: A conflict of interest between plants and bees? Oecologia, 186, 163-171.

Tong ZY, Xu HL, Huang SQ (2018) Examining methodologies of pollinator detection in the field. Biodiversity Science, 26, 433-444. (in Chinese with English abstract) [童泽宇, 徐环 李, 黄双全 (2018) 探讨监测传粉者的方法. 生物多样 性, 26, 433-444.]

Wang J, Zhai YX, Zhang AQ (2018) Temporal variation of plant sexes in a wild population of Tulipa sinkiangensis over seven years. Biodiversity Science, 26, 519-526. (in Chinese with English abstract) [王娟, 翟雅芯, 张爱勤 (2018) 新 疆郁金香一居群个体性别7年的动态变化. 生物多样性, 26, 519-526.]

Wang YX, Liu ZJ, Zhao ZG, Hou M, Zhang XR, Lü WL (2018) Responses of floral longevity to pollination environments in 11 species from two alpine meadows. Biodiversity Science, 26, 510-518. (in Chinese with English abstract) [王玉贤, 刘左军, 赵志刚, 侯盟, 张小瑞, 吕婉灵 (2018) 青藏高原高寒草甸植物花寿命对传粉环境的响 应. 生物多样性, 26, 510-518.]

Wilson P, Thomson JD (1991) Heterogeneity among floral visitors leads to discordance between removal and deposition of pollen. Ecology, 72, 1503-1507.

Xie ZH, Xu HL, Yang P (2011) Notes on monitoring, assessing and conserving pollinator biodiversity. Chinese Journal of Applied Entomology, 48, 746-752. (in Chinese with English abstract) [谢正华, 徐环李, 杨璞 (2011) 传粉昆虫物种多 样性监测、评估和保护概述. 应用昆虫学报, 48, 746-752.]

Xu HL, Yang JW, Sun JR (2009) Current status on the study of wild bee-pollinators and conservation strategies in China. Acta Phytophylacica Sinica, 36, 371-376. (in Chinese with English abstract) [徐环李, 杨俊伟, 孙洁茹 (2009) 我国 野生传粉蜂的研究现状与保护策略. 植物保护学报, 36, 371-376. ]

Yang P, Peng YQ, Zhao RH, Yang DR (2018) Biological characteristics, threat factors and conservation strategies for the giant honey bee Apis dorsata. Biodiversity Science, 26, 476-485. (in Chinese with English abstract) [杨培, 彭艳琼, 赵荣华, 杨大荣 (2018) 大蜜蜂的生物学特性、面临威胁 与保护策略. 生物多样性, 26, 476-485.]

Zhu YQ (1957) Floral nectar of Camellia oleifera seems to be poisonous to honeybees. Apiculture of China, 4, 5-6. (in Chinese) [ 朱永谦 (1957) 油茶花蜜对蜜蜂有毒的问题. 中国养蜂, 4, 5-6.]

(责任编辑: 周玉荣) 